\title{
Effect of Water Salinity on Some Blood Parameters of Common Carp (Cyprinus carpio)
}

\author{
Hasan A. Al Hilali, Mohammed S. Al-Khshali \\ Department of Animal Resources, College of Agriculture, University of Baghdad, Baghdad, Iraq
}

Email address:

Hassanalhilaly89@gmail.com (H. A. Al Hilalli), alshaker64@yahoo.com (M. S. Al-Khshali)

\section{To cite this article:}

Hasan A. Al Hilali, Mohammed S. Al-Khshali. Effect of Water Salinity on Some Blood Parameters of Common Carp (Cyprinus carpio). International Journal of Applied Agricultural Sciences. Vol. 2, No. 1, 2016, pp. 17-20. doi: 10.11648/j.ijaas.20160201.13

\begin{abstract}
This study was conducted to investigate the effect of high salinity on the blood parameters of common carp (Cyprinus carpio) which gradually exposed to salt concentrations of 5, 10 and $15 \mathrm{~g} / \mathrm{liter}$, as well as tap water (control $0.1 \mathrm{~g} /$ liter). 80 fish were randomly distributed to four salinity treatments with 2 replicates /treatment (10 fish / replicate) at average weight of $15 \pm 3 \mathrm{~g}$ to study the effect of salinity on the blood parameters, which included packed cells volume(PCV), red blood cells (RBC), white blood cells (RBC) and hemoglobin (Hb). Results showed an increase in the (PCV) to 36.17, 40.15 to and $45.30 \%$ when the salinity increased to 5,10 and $15 \mathrm{~g} / 1$ respectively, compared with the control treatment (33.14\%). $\mathrm{Hb}$ reached $13.34,14.56$ and $15.80 \mathrm{mg} / 100 \mathrm{ml}$ at the concentration of 5,10 and 15 respectively, compared with the control treatment $(12.15 \mathrm{mg} / 100 \mathrm{ml})$. RBC reached $2.80,2.93$ and $3.1 \times 10^{6}$ cells $/ \mathrm{mm}^{3}$ respectively, in comparison with control $(0.1$ $\mathrm{g} / \mathrm{l}$ ), while the WBC increased to $12.88,15.23$ and $10.55 \times 10^{3}$ cells $/ \mathrm{mm}^{3}$ when the salt concentrations were 5,10 and $15 \mathrm{~g} / 1$ respectively, compared with control $\left(10.44 \times 10^{3}\right.$ cells $\left./ \mathrm{mm}^{3}\right)$.
\end{abstract}

Keywords: Salinity, Blood Parameters, Cyprinus carpio

\section{Introduction}

Aquaculture plays an important role in solving the famine and malnutrition crisis over the world through the provision of fish and other aquatic organisms that rich in protein, vitamins, minerals and amino acids. The rapid development of aquaculture in the world has led to produce more than 123 species of fish in intensive culture and non-intensive systems, so in order to achieve good growth rates in aquaculture have to be fish of good health and resistance to disease, as well as the availability of good water quality [1]. The quality and quantity of feed is not enough to get a high production of fish, as the environmental conditions are also have a vital role in order to get a large production. Salinity is one of these factors are very important with temperature and oxygen and have a direct impact on fish growth [2].

Iraqi inland water is exposing to continuous rise in salinity levels currently due to several reasons, including the scarcity of water releases of Tigris and Euphrates rivers and the impact of salt water drain that entering Iraq, besides drying of large areas of the marshes and the lack of rain [3]. The salinity of the marshes water in southern region of Iraq ranged from 2.20 to $3.82 \mathrm{~g} / 1$ and is rising rapidly[4], as well as increasing of evaporation rates due to rising of the temperatures and global warming rates.

Any disorder in fish environment such as changes in the concentrations of salinity is representing a major factor in the imbalance of the internal stability (Homeostasis), so fish need many of the physiological responses for a return to stability as they were before exposure to the stressor factor [5]. First effect of salinity appeared on fish through the influencing of osmoregulation process as an effect of take or loss of ions in high or low salinity in order to maintain the ions concentration and liquids inside the body via the functions of the organs that responsible for osmoregulation (gills, kidney and intestine) that blood is the most sensitive for the changes in salinity. This study was conducted to investigate the effect of high salinity on some blood factors (percentage of haematocrit and hemoglobin concentration).

\section{Materials and Methods}

A total of 80 common carp at average weight of $15 \pm 3 \mathrm{~g}$ were distributed on four different salinity treatments $(0.1,5$, 10 and $15 \mathrm{~g} / \mathrm{l}$ ) and tested in two replicates for each salinity treatment. Fish were acclimated to the laboratory conditions for 3 weeks before the experiment started, fish were not fed 
for $24 \mathrm{~h}$ before they were transferred to experimental tank. There were 10 fish in each tank, fed on a diet with $31 \%$ protein content (table 1) at a ratio of $4 \%$ of body weight, twice a day.

Table 1. Chemical analysis of diet $\%$.

\begin{tabular}{ll}
\hline protein & $\mathbf{3 1} \pm \mathbf{0 . 9}$ \\
\hline Fat & $9.0 \pm 0.2$ \\
Moisture & $8.66 \pm 0.21$ \\
ash & $11.4 \pm 1.2$ \\
fiber & $40.88 \pm 0.12$ \\
\hline
\end{tabular}

Salt concentrations were prepared by dissolution of specific weight of salt in liter of tap water, and fish were exposed to gradual salt concentration of 5,10 and $15 \mathrm{~g} / \mathrm{l}$. while the tap water concentration $(0.1 \mathrm{~g} / \mathrm{l})$ was represented control treatment. Standard haematological analysis procedures described by [6] were employed in the assessment of the various blood parameters, Hemoglobin $(\mathrm{Hb})$ was done by the cyanomethaemoglobin method packed cells volume (PCV) by micro haematocrit method, the account number of red and white blood cells were assessed by the method of [7]. Statistical analysis system [8] and completely random design were used to analyze the data of experiment.

\section{Results}

Table 2 showed a significant increase in blood haematocrit (PCV), hemoglobin ( $\mathrm{Hb})$, red blood cells (RBC) and white blood cells (WBC), when the salt concentrations gradually rose to 5,10 and $15 \mathrm{~g} / 1$. The results of the statistical analysis showed non- significant differences $(\mathrm{P} \geq 0.05)$ in haematocrit between the control treatments and the concentration of $5 \mathrm{~g} / 1$, while there were significant differences $(\mathrm{P} \leq 0.05)$ between the concentrations of 10 and $15 \mathrm{~g} / \mathrm{l}$. As well as in hemoglobin there was non-significant difference between the control and $5 \mathrm{~g} / \mathrm{l}$,, in the red blood cells, there were a significant differences between control treatment and other treatments in the experiment, while there were non-significant differences $(\mathrm{P} \geq 0.05)$ between 10 and $15 \mathrm{~g} /$ liter. In the white blood cells, there was a significant difference between all treatments.

Table 2. Blood concentrations of PCV, Hb and RBC and WBC in different salt concentrations of common carp (values \pm standard error).

\begin{tabular}{lllll}
\hline Salinity g/l & PCV \% & Hb gm/100ml & Red blood cells $\mathbf{1 0}^{\mathbf{6}} \times \mathbf{m m}^{\mathbf{3}}$ & White blood cells $\mathbf{1 0} \times \mathbf{m m}^{\mathbf{3}}$ \\
\hline 0.1 & $0.97 \pm 33.14 \mathrm{c}$ & $0.25 \pm 12.15 \mathrm{~b}$ & $0.04 \pm 2.80 \mathrm{c}$ & $0.01 \pm 10.44 \mathrm{c}$ \\
5 & $2.84 \pm 36.17 \mathrm{c}$ & $0.52 \pm 13.34 \mathrm{~b}$ & $0.06 \pm 2.87 \mathrm{~b}$ & $0.02 \pm 12.88 \mathrm{~b}$ \\
10 & $3.34 \pm 40.15 \mathrm{~b}$ & $14.56 \pm 1.64 \mathrm{a}$ & $0.03 \pm 2.93 \mathrm{a}$ & $0.01 \pm 15.23 \mathrm{a}$ \\
15 & $5.41 \pm 45.30 \mathrm{a}$ & $0.68 \pm 15.80 \mathrm{a}$ & $0.11 \pm 3.1 \mathrm{a}$ & $0.03 \pm 10.55 \mathrm{c}$ \\
\hline
\end{tabular}

Different letters refer to significant differences between treatments

\section{Discussion}

Blood measurements have been considered an important parameters for the healthy status for any organisms. Fish exposed to the stress will be suffer a physiological changes so as to preserve the consistence and body stability, where the increase of PCV result from to losing of much quantity of water because of the difference between the internal and external environment ions concentrations. which led to get out the water as a result of osmosis pressure and then increasing the percentage of PCV. The increase of RBC may be resulted by the increase of oxygen consumption owing to the increase of energy requirement. Besides, $\mathrm{RBC}$ have an important role to transfer the oxygen, while the increase in WBC may be related to immunity reaction because of raising the cortisol hormone that is responsible for organizing the osmosis in salt water or might be the transferring of WBC throughout the body as existing of factor leading to facilitate the infection of fish with diseases, moreover, the increase in hemoglobin is leading to increase in $\mathrm{RBC}$ as hemoglobin regarded as protein carried by $\mathrm{RBC}$ and having a role in respiration.

It has been noticed there is a fluctuation in PCV of common carp that gradually being transferred to different salt concentrations. The increase in water salinity is actually accompanied with the increase in PCV, $>$ where this increase could be result from the loose of a quantity of water from the blood owing to osmosis differences between the blood and the external environment [9]. This increase could be attributed to the increase in the numbers of $\mathrm{RBC}$ as a reaction to overcome the rising demand for the oxygen consumption resulted from increasing of metabolism and ultimately lead to increasing in PCV [9]. This explanation might be the suitable one for explaining reasons of raise in PCV with the increasing of salt concentration as that indicated by the results of the current study. This raise is timed with the increase of oxygen consumption rate to satisfy for responding the additional energy requirements under conditions of salt stress for carrying out the osmoregulation. The increase in hemoglobin concentrations has been considered as a vital indicator for any environmental change [10]. The increase in concentration of hemoglobin might be as a result of being exposed to the salt. The white blood cells were decreased in $15 \mathrm{~g} / 1$ salt concentration, that is may be attributed to the salt stress that led to reduction in numbers of WBCs and fish's immunity minimizing.

The blood parameters in fish have reflected its healthy state and have given the physiological responses to the factors as a result of the effect of environmental factors [11]. [12] revealed that any change in blood criteria has been considered as part of preliminary response for stress, so long as the salinity considered as a stressor factor, actually it leads to either increase or decrease in of blood parameters. Thus the alter in blood parameters refers to keep away of fish the from balance and considered as physiological endeavor to get back to the internal stability after exposing to different salt concentrations [13]. This might have led to occurring 
changes in of oxygen consumption rate and energy consumed and change in ions transfer across gills via increasing the blood factors that working as an intermediate for achieving the increase in oxygen and transferring ions across blood [14]. The increase in RBCare mostly ensued from spleen that is responsible for generating these cells that got swollen owing to stress and works on increasing $\mathrm{RBC}$ and hemoglobin as a physiological reaction for increasing in salt [15]. The RBC in fish have the ability to get shrinkage and swelling depending on the salt surrounded the fish [16] moreover, the increase in $\mathrm{RBC}$ and PCV might be caused by the differences in water quantity in blood or it could be interpreted that the high salinity increased the number of $\mathrm{RBC}$ for meeting the increasing request on oxygen consumption sufficiently for consuming additional energy during oxidation against osmoses and ionicstress that ultimately leading to increasing the size of PCV and hemoglobin concentration. where the relationship between $\mathrm{RBC}$ and $\mathrm{PCV}$ is a positive one [17]. The increase in hemoglobin has conformed with results of [18] when exposing the common carp to high concentrations of $\mathrm{NaCl}$, and agree with results of [19] when exposing Carassiusauratus to high and low temperature that being considered as a stress factor. it has been obtained the same results in the experience of [20] on common carp when exposed to low temperature. These results have conformed to many studies, [21] has mentioned that the gradually transfer of grass Carp Ctenopharyngodon idella to the salt concentrations of $4,8,12 \mathrm{~g} / 1$ led to increasing PCV [22] has referred that the sudden transfer for Barbus sharpeyi to salts $10.9,12,5 \mathrm{~g} / 1$ and gradual transfer to the salt 7.1, 9.1 and $10.9 \mathrm{~g} / 1$ led to increase the PCV, referring that the increase of environment salinity caused increasing in taking Sodium by $\mathrm{RBC}$ that being formed a hyposmotic environment, in comparison with the external environment, causing swelling the in $\mathrm{RBC}$, which reflected on increasing of PCV and plasma dryness [23]. [24] noticed an increase in the PCV of Acanthopagrus latus when exposed to different salt concentrations after 24 hours of exposure, the main reasons are related to the lose water from blood owing to increasing in osmosis differences between the blood and external environment. [25] has reached to the same result and given reasons for increasing PCV in the first stages of acclimation to the salt water that are related to the change in water content in the blood owing to the change in salinity of environment. The water has been relatively lost in high salinities and as a result ti the increase of to the increase water swelling for compensation, the values get back to its preliminary levels [9] have recorded increase in PCV during the first stage of transfer the fish of Acipenser naccarii to the salt concentration of salt $35 \mathrm{~g} / \mathrm{l}$, but after 21 days got back to its preliminary values. It has been noticed increase in PCV cells in the fish Pomacanthus imperator that being transferred to the salt $15,22 \mathrm{~g} / 1$ in comparison with the sea water salt of $33 \mathrm{~g} / 1$ [26]. Both researchers have ascribed this change in PCV to the change in numbers and size of RBC or to the change in size of Plasma owing to drinking salt water depending on the fish species [27]. The results got different with other studies [28] have found that the PCV in the fish of Chinook salmon gets decreased with increasing salt and the reduction was significant at salt concentration of $20,28 \mathrm{~g} / \mathrm{l}$, it amounted $32 \%$ in comparison with water $(41 \%$,) while [29] noticed that the transfer of Liza abu to salt $7 \mathrm{~g} / 1$ has not yet caused differences in values of PCV in comparison with the fish existing in fresh water, where the value of PCV amounted $37.67 \%$ at salinity $7 \mathrm{~g} / 1$ by compared with fresh water $35.17 \%$, while the transferring to the salt $15 \mathrm{~g} / 1$ resulted in reduction in PCV (21.6\%). The increase in $\mathrm{WBC}$ in the current study with increasing in salts concentrations up to 5 , 10 and $15 \mathrm{~g} / \mathrm{l}$. could be attributed to the increase of WBC immigration across plasma [30] It could have been also interpreted the increase in $\mathrm{RBC}$ and $\mathrm{WBC}$ as an immunity reaction owing to the fish expose to the stress due to the internal effect of cortisol and growth hormones's and return to the balance state of ions and water and getting the fish back to the state of internal stability. This conform to the results of [31] on canal catfish, that transferred from its environment where salt reached to $12 \mathrm{gm} / 1$ it to the laboratory where the fish have been gradually exposed to salt ranging from $2 \mathrm{~g} / 1$ to $34.0 \mathrm{~g} / 1$ for 7 days. the increase in salt concentrations resulted in increasing WBCs and RBC. The increase in concentration of hemoglobin and PCV for common carp in this study was similar to results of [32] who has exposed grass carp to the different salt concentrations, while [33] in his study on Tilapia Oreochromis niloticus where he used salt concentrations of fresh water, 5,10 and 15 $\mathrm{g} / \mathrm{l}$. on adult fish, he noticed the effect of salt on metabolism and blood aspects he found the effect of salt on blood characteristics has been more larger in the young fish than in fingerlings. The increase has occurred in each of RBCs and WBC, hemoglobin and PCV.

\section{References}

[1] Fazio, A., Marafioti, S., Arfuso, F., Piccione, G., \& Faggio, C. (2013). Influence of different salinity on haematological and biochemical parameters of the widely cultured mullet, Mugil cephalus. Marine and Freshwater Behaviour and Physiology, 46(4), 211-218.

[2] Mommsen, T. (1998). Growth and metabolism. In D. Evans, The Physiology of Fishes, Second edititon (p. 65). Boca Raton: CRC Press.

[3] Al-Faiz N, A, Jabir, A, A, Yesser, A, K.(2009) Variance salinity concentrations effects on survival, growth and feeding of common carp (Cyprinus carpio) fingerlings Iraqi $\mathrm{J}$. Aquacul. 6 (2), 59-70.

[4] Al-Najjar, G, A (2009). Quarterly changes in the concentration of heavy metals in the muscles of three types of family cyprinidae in lhoveizeh Marsh and eastern ALhamar (Thesis, University of Basra) P 78.

[5] Enayati, A., Peyghan, R., Papahn, A. A., \& Khadjeh, G. H. (2013). Study on effect of salinity level of water on electrocardiogram and some of blood serum minerals in grass carp, Ctenopharyngodon idella. Vet Res Forum,4(1), 49-53. 
[6] Blaxhall, B. C., \& Daisleey, K. W. (1973). Routine haematological methods for use with fish blood. J. Fish Bid, $5,771-78$.

[7] Natt, M. P., \& Herrick, C. A. (1952). Anew blood diluent for counting the erythrocytes and the leucocytes of the chicken. poultry sci.; 31, 735-738.

[8] SAS. (2004). SAS User's Guide: Statistics Version 6th ed., SAS Institute Inc.

[9] Martinez-Alvarez, R. M., Hidalgo, M. C., Domezain, A., Morales, A. E., Garcia - Gallego, M., \& Sanz, A. (2002). Physiological changes of Sturgeon (Acipenser naccarii) caused by increasing environmental salinity. J. Exp. Biol 202, 3699-3706.

[10] Bani, A., \& Haghi Vayghan, A. (2009). Temporal variation in Haenatological and Biochemical Indices of the Caspian Kutum RutilusFrisii Kutum. Ichthyological Society of Japan, 126-133.

[11] Schutt, D. A., Lehmann, J., Goerlich, R., \& Hamers, R. (1997). Haematology of swordtail Xiphophorous helleri. I: blood parameters and light microscopy of blood cells. Journal of Applied Ichthyology 13(2): 83-89.

[12] McCormick, S. D. (2001). Endocrine control of osmoregulation in fish. American Zoologist 41, 781-794.

[13] Schreck, C. B. (1990). Physiological behavioral and performance indicators of stress Adams S M biological Indicators of stress. Bethesda USA: American Fisheries Society.

[14] Akinrotimi, O. A., Gabriel, U. U., Anyanwu, P. E., \& Anyanwu, A. O. (2007). Influence of sex, acclimation methods and period on haematology of Sarotherodon melanotheron. Research Journal of Biological Sciences 2(3), 348-352.

[15] Milligan, C. L., \& wood, C. M. (1982). Distrbances in hematology, fluid volume distribution and circulatory function associated with low environmental ph in the rainbow trout salmo gairdneri. J. EXP. Biol. 99, 397-415.

[16] Assem, H. (1981). Problem of osmomineral regulation in euryhaline teleost, sartherodon mossambicus. karlsruhe Germ: $\mathrm{Ph}$. D. thesis. univ.

[17] Brown, J. A., Moore, W. M., \& Quabius, E. S. (2001). Physiological effects of saline waters on zander. J. Fish Biol., 59: $1544-1555$.

[18] Hafez amini, P., \& Oryan, S. H. (2002). Effect of $\mathrm{NaCl}$ stress on Hematocrit and Hemoglobin Common Carp (Cyprinus carpio). Iranian Fisheries Jornal, 3, 13-22.

[19] Houston, A. H., \& Rupert, R. (1997). Immidiate response of hemoglobin system of gold fish(Carassius auratus) to temperature change. Can. J. of Zoology, 54, 1731-174.

[20] Chen, G. R., Sun, L. T., Lee, Y. H., \& Chang, C. F. (1995). Characteristics of blood in common carp, Cyprinus carpio, exposed to low temperature. J. of Applied Aquaculture, 5(3), 21-31.
[21] Al-khshali, M. S. (2011), Effect of different salt concentrations on some physiological and nutritional aspects of grass carp Ctenopharyngodon idella and gold fish Carassius auratus, University of Baghdad, Ph.D Thesis p. 120.

[22] Salman, N. A. (1997). Osmoregulatory functions in Bunni Barbus sharpeyi in response to short-term exposure to salt water. Bas. J. Sci., 15(1), 7-14.

[23] Eddy, F. (1982). Osmotic and ionic regulation in captive fish with. Comp.Biochem.Physiol., 73B.(1)125-141.

[24] Sultan, F, A. (2007) Effect of Salinity Acclimation on some Physiological an Nutritional aspects in Acanthopagrus latus (Houttyn, 1782) Juveniles. University of Basrah, ph.D thesis., P162.

[25] Plaut, I. (1998). Comparison of salinity tolerance and osmoregulation in two closely related species of blennies from different habitats. Fish Physiol. Biochem. 19, 181-188.

[26] Woo, N. Y., \& Chung, K. (1995). Tolerance of Pomacanthus imperator to hypo-osmotic salinities: changes in body composition and hepatic enzyme activities. J. Fish Biol., 47, 70-81.

[27] Talbot, C. (1992). Laboratory method in fish feeding and nutritional studies. In P. Tyler, \& P. Calow, Fish energetics New perspectives (pp. 125-154). London: Croom Helm.

[28] Morgan, J. D., \& Iwama, G. K. (1991). Effects of salinity on growth, metabolism, and ion regulation in juvenile rainbow trout (Oncorhynchus mykiss) and fall Chinook salmon (Oncorhynchus tshawytscha). Can. J. Fish. Aqua. Sci., 48 (11), 2083-2094.

[29] Ahmed, S. M., Al-Dubiakel, A. Y., \& Mohamed, F. A. (2004). Changes in alkaline phosphatase activity in the intestine of (Liza abu) Juveniles during salinity acclimation. Iraq. J. Aqua., 11, 17-27.

[30] Gomes, L. C., King, E. J., \& Kebus, M. J. (2003). Effect of Fish density during transportation on stress and mortality of Juvenile tambaqui Colossima macroponnum. Journal of World Aquaculture Society 34, 76-84.

[31] Eckert, S. E., Yadal, T., Stephand, K. L., Steston, M. H., Hirano, T., \& Grau, E. G. (2001). otmonal Control of osmo Regulation in the channel catfish Ictalurus punctatus. Comp. Endocrinol.,.: 65: 201-234.

[32] Yavuzcan-Yildiz, H., \& Kirkavgaç-Uzbilek, M. (2001). The evaluation of secondary stress response of grass carp (Ctenopharyngodon idella, Val. 1844) after exposing to the Saline water. Fish Physiol. Biochem. 25(4), 287-290.

[33] Akinrotimi, O. A., Agokei, E. O., \& Aranyo, A. A. (2012). Changes in Blood Parameters of Tilapia Guineensis Exposed to Different Salinity Levels. JOURNAL OF ENVIRONMENTAL ENGINEERING AND TECHNOLOGY, 1(2), online. 